\title{
Chronic Liver Disease: Differences in Autoimmune Serological Reactions between Australians and Asians
}

\author{
SENGA WHITTINGHAM, IAN R. MACKAY, R. S. THANABALASUNDRUM, H. K. CHUTTANI \\ R. MANJURAN, C. S. SEAH, M. YU, V. VIRANUVATTI
}

\begin{abstract}
Design of Study
Sera from patients with long-standing jaundice or cirrhosis or both diseases from Australia, Ceylon, India, Singapore, and Thailand were coded and referred for serological tests which were done in Melbourne. Patients with liver disease due to extrahepatic obstruction, cancer, parasitism, heredofamilial disorders, or alcoholism were excluded. Histological assessment of liver biopsy specimens was made locally. The criteria for case selection were chronic jaundice attributable to chronic hepatitis or cirrhosis or, if jaundice was not present, clear evidence of established cirrhosis of the "cryptogenic" type.
\end{abstract}

\section{Patients and Methods}

The Australian (Caucasian) cases were randomly selected on a prospective basis. They were drawn from a survey over one year of patients in the Royal Melbourne Hospital considered to require a biopsy for diagnostic purposes (Bhathal et al., 1973). Included in this survey were 205 patients, 18 of whom had non-alcoholic cirrhosis, seven had cryptogenic cirrhosis, eight had cirrhosis associated with active chronic hepatitis, one had primary biliary cirrhosis, and two had haemochromatosis (see table). This particular method of selection yielded relatively few cases, but was used to avoid bias.

The Ceylonese cases were drawn fron the practice of a consultant physician. The 14 patients included nine with cryptogenic cirrhosis, three with active chronic hepatitis, and two with biliary cirrhosis.

The Indian cases were selected randomly from patients attending the department of medicine of the Maulana Azad Medical College and Associated Irwin and G. B. Pant Hospitals, New Delhi, according to the criterion of prolonged jaundice lasting for at least six months. The 54 patients included 10 with cryptogenic cirrhosis, two with active chronic hepatitis, and 42 with chronic hepatitis of unspecified type.

The Singaporean cases were selected randomly from patients attending the General Hospital, Singapore, on the basis of a diagnosis of cryptogenic cirrhosis. The $\mathbf{4 0}$ patients included 37 Chinese, two Indians, and one Malay.

The Thai cases were selected randomly from patients attending the Siriraj Hospital, Bangkok, according to the criterion of prolonged jaundice. The 38 patients included 20 with cryptogenic cirrhosis, three with active chronic hepatitis, three with biliary cirrhosis, and 12 with chronic hepatitis of unspecified type.

Serological Tests.-Serum from each of the 164 patients was tested for autoantibodies (Whittingham and Mackay, 1969) by immunofluorescence. Tests were made for antinuclear antibodies by using polymorphonuclear leucocytes and lymphocytes from human blood; smooth muscle antibodies by using rat stomach; mitochondrial antibodies by using mouse kidney; and gastric parietal cell and thyroid epithelial cell antibodies by using human stomach and human thyroid gland. Sera containing antinuclear antibodies were titrated in tenfold dilutions and the results expressed in units per $\mathrm{ml}$ (Whittingham, 1972), and sera containing other autoantibodies were titrated in doubling dilutions, the results being expressed as the reciprocal of the dilution. The diluent used was phosphate-buffered saline $\mathrm{pH} 7 \cdot 3$

Department of Medicine, Siriraj Hospital, Mahidol University, Bangkok, Thailand

V. VIRANUVATTI, M.D., F.R.C.P., Chairman 
Prevalence of Autoantibodies and Hepatitis Antigen (HBAg), and Mean Level of Gammaglobulin in 164 Patients with Chronic Liver Disease from various Asian Countries

\begin{tabular}{|c|c|c|c|c|c|c|c|c|c|c|c|}
\hline & & & & \multirow{2}{*}{$\begin{array}{l}\text { No. } \\
\text { Tested }\end{array}$} & \multirow[b]{2}{*}{$\begin{array}{l}\text { MeanY } \\
\text { Globulin } \\
(\mathrm{g} / \mathrm{ml})\end{array}$} & \multirow{2}{*}{$\begin{array}{c}\text { No. } \\
\text { with } \\
\text { HBAg }\end{array}$} & \multicolumn{5}{|c|}{ No. with Autoantibodies to } \\
\hline & & & & & & & Nuclei & $\begin{array}{l}\text { Smooth } \\
\text { Muscle }\end{array}$ & $\begin{array}{l}\text { Mito- } \\
\text { chondria }\end{array}$ & $\begin{array}{c}\text { Nuclei, } \\
\text { Smooth Muscle } \\
\text { and/or Mito- } \\
\text { chondria }\end{array}$ & $\begin{array}{c}\text { Gastric } \\
\text { Parietal } \\
\text { and/or } \\
\text { Thyroid Cells }\end{array}$ \\
\hline $\begin{array}{l}\text { Australians: } \\
\text { Cryptogenic cirrhosis } \\
\text { Active chronic hepatitis } \\
\text { Primary biliary cirrhosis } \\
\text { Haemochromatosis .. }\end{array}$ & $\begin{array}{l}\cdots \\
\cdots \\
\cdots\end{array}$ & $\begin{array}{l}\cdots \\
\cdots \\
\cdots\end{array}$ & $\begin{array}{l}\cdots \\
\therefore \\
\cdots\end{array}$ & $\begin{array}{l}7 \\
8 \\
1 \\
2\end{array}$ & $\begin{array}{l}1.7 \\
2.7 \\
1.9 \\
0.9\end{array}$ & $\begin{array}{l}2 \\
0 \\
0 \\
0\end{array}$ & $\begin{array}{l}3 \\
5 \\
0 \\
0\end{array}$ & $\begin{array}{l}\mathbf{0} \\
\mathbf{5} \\
0 \\
0\end{array}$ & $\begin{array}{l}0 \\
0 \\
1^{*} \\
0\end{array}$ & $\begin{array}{l}3 \\
6 \\
1 \\
0\end{array}$ & $\begin{array}{l}3 \\
1 \\
0 \\
0\end{array}$ \\
\hline Total & . & . & $\ldots$ & 18 & $1 \cdot 8$ & $11 \%$ & $44 \%$ & $27 \%$ & $5 \%$ & $55 \%(P<0.001)$ & $22 \%(P<0.05)$ \\
\hline $\begin{array}{l}\text { Ceylonese: } \\
\text { Cryptogenic cirrhosis } \\
\text { Active chronic hepatitis } \\
\text { Biliary cirrhosis } \quad . .\end{array}$ & $\begin{array}{l}\cdots \\
\cdots\end{array}$ & $\begin{array}{l}\cdots \\
\therefore\end{array}$ & $\begin{array}{l}\cdots \\
\cdots\end{array}$ & $\begin{array}{l}9 \\
3 \\
2\end{array}$ & $\begin{array}{l}1.5 \\
1.6 \\
2.3\end{array}$ & $\begin{array}{l}1 \\
0 \\
0\end{array}$ & $\begin{array}{l}1 \\
0 \\
0\end{array}$ & $\begin{array}{l}1 \dagger \\
0 \\
0\end{array}$ & $\begin{array}{l}0 \\
0 \\
0\end{array}$ & $\begin{array}{l}2 \\
0 \\
0\end{array}$ & $\begin{array}{l}1 \\
0 \\
0\end{array}$ \\
\hline Total & .. & $\ldots$ & $\ldots$ & 14 & $1 \cdot 8$ & $7 \%$ & $7 \%$ & $7 \%$ & 0 & $14 \%(P<0.05)$ & $7 \%$ N.S. \\
\hline $\begin{array}{l}\text { Indians: } \\
\text { Cryptogenic cirrhosis } \\
\text { Active chronic hepatitis } \\
\text { Chronic hepatitis of unspeci }\end{array}$ & cified typ & $\ddot{x}$ & $\begin{array}{l}\cdots \\
\cdots\end{array}$ & $\begin{array}{r}10 \\
2 \\
42\end{array}$ & $\begin{array}{l}1.5 \\
1.5 \\
1.2\end{array}$ & $\begin{array}{l}0 \\
0 \\
5\end{array}$ & $\begin{array}{l}1 \\
0 \\
0\end{array}$ & $\begin{array}{l}3 \\
0 \\
2\end{array}$ & $\begin{array}{l}0 \\
0 \\
0\end{array}$ & $\begin{array}{l}\mathbf{4} \\
0 \\
2\end{array}$ & $\begin{array}{l}0 \\
1 \\
3\end{array}$ \\
\hline Total & .. & $\ldots$ & $\ldots$ & 54 & $1 \cdot 3$ & $9 \%$ & $2 \%$ & $9 \%$ & 0 & $11 \%(P<0.001)$ & $7 \%$ N.S. \\
\hline $\begin{array}{l}\text { Singaporeans: } \\
\text { Cryptogenic cirrhosis }\end{array}$ & .. & $\cdots$ & .. & 40 & 1.4 & 0 & 0 & 0 & 0 & $0(P<0.001)$ & $0(P<0.01)$ \\
\hline $\begin{array}{l}\text { Thai: } \\
\text { Cryptogenic cirrhosis } \\
\text { Active chronic hepatitis } \\
\text { Biliary cirrhosis } \\
\text { Chronic hepatitis of unspeci }\end{array}$ & $\begin{array}{l}\cdots \\
\because \\
\text { cified typ }\end{array}$ & $\begin{array}{l}\cdots \\
\because \\
\ddot{p e}\end{array}$ & $\begin{array}{l}\ldots \\
\cdots \\
\cdots\end{array}$ & $\begin{array}{r}20 \\
3 \\
3 \\
12\end{array}$ & $\begin{array}{l}2 \cdot 0 \\
1 \cdot 5 \\
0 \cdot 6 \\
2 \cdot 0\end{array}$ & $\begin{array}{l}\mathbf{0} \\
\mathbf{0} \\
\mathbf{0} \\
\mathbf{0}\end{array}$ & $\begin{array}{l}1 \\
1 \\
1 \\
0\end{array}$ & $\begin{array}{l}0 \\
0 \\
0 \\
0\end{array}$ & $\begin{array}{l}\mathbf{0} \\
0 \\
0 \\
0\end{array}$ & $\begin{array}{l}1 \\
1 \\
1 \\
0\end{array}$ & $\begin{array}{l}2 \\
0 \\
0 \\
0\end{array}$ \\
\hline Total & $\ldots$ & $\ldots$ & $\ldots$ & 38 & 1.5 & 0 & $8 \%$ & 0 & 0 & $8 \%(P<0.001)$ & $5 \%$ N.S. \\
\hline
\end{tabular}

*Titre $=256$.

Statistical analyses were applied to differences between Australians and Asians from all countries, and between Australians and Asians from individual countries, for antibodies to nuclei, smooth muscle, and mitochondrial-that is, combined "liver" autoantibodies, and thyroid and gastric or "non-liver" autoantibodies.

to nuclei, smooth musct.

containing $0.05 \%$ bovine serum albumin. The sera were tested for hepatitis B antigen (HBAg) by cross-over immunoelectrophoresis (Gust and Kaldor, 1971), and for the level of gammaglobulin by a zinc sulphate turbidity reaction (Weiden, 1953). $\chi^{2}$ tests were used for statistical analyses.

\section{Results}

The prevalence of the autoantibodies, hepatitis B antigen, and level of gammaglobulin in the 164 patients studied is set out in the table. Noteworthy is the high prevalence of autoantibodies associated with chronic "idiopathic" liver disease among Australians ( $55 \%$ ) compared with those from the Asian countries $(0-14 \%)$. The levels of these autoantibodies were also high among Australians in that antinuclear antibodies ranged up to $167 \mathrm{units} / \mathrm{ml}$ and smooth muscle antibodies up to a titre of 512; the maximum level of antinuclear antibodies among the Asian patients was 167 units $/ \mathrm{ml}$ and the highest titre of smooth muscle antibodies was 128 . In none of the groups was there a high prevalence of HBAg.

\section{Discussion}

Our study appears to be the first recorded attempt to examine the prevalence of chronic liver disease with autoimmune features among various racial groups. International surveys of this nature are beset with difficulties because of differences from country to country in nomenclature, definition, and classification of chronic liver disease. None the less, we believe that the criteria applied to the selection of the 164 cases of liver disease in this study gave us valid groups for comparison. The high prevalence of autoantibodies to nuclei, smooth muscle, and mitochondria known to be associated with chronic liver disease in Australian Caucasians was in contrast to the lower prevalence detected among Indians, Ceylonese, Thais, and Singaporean Chinese with chronic liver disease. Studies from Uganda (Doniach, 1972), Singapore (Fung et al., 1972), and Hong Kong (Lee, 1973) have likewise shown a low prevalence of autoantibodies among non-Caucasians with chronic liver disease. Thus the autoimmune (lupoid) type of chronic hepatitis and primary biliary cirrhosis may vary in prevalence among races; the same has been said of the autoimmune type of gastritis, the precursor of pernicious anaemia (Irvine et al., 1969).

The main explanations for differences in prevalence and type of liver diseases among racial groups would include differing exposure or susceptibility to infectious agents or toxic agents, nutritional differences, anci inter-racial genetic differences. In Australia transmissible agents, particularly hepatitis B virus, have not been recognized as important causes of hepatitis (Mathews and Mackay, 1970; Cooksley et al., 1972). The incidence of HBAg was also low among the South-east Asian sera and this was not due to selection of patients. We note that higher prevalences of HBAg in chronic liver disease have been reported from Austria, Greece, and Uganda (Wells and Fudenberg, 1972), Kenya (Bagshawe et al., 1971), Italy (Bianchi et al., 1972), and Hong Kong (Lee, 1973). The possible role of toxic and nutritional factors in chronic hepatitis is still undefined, particularly in Asian communities. Familial aggregations of active chronic hepatitis and immune disorders have been only occasionally reported (Joske and Laurence, 1970; Whittingham et al., 1970; Hilberg et al., 1971), but among Australian patients with autoimmune active chronic hepatitis there is a high frequency of two histocompatibility antigens HL-A1 and HL-A8 (Mackay and Morris, 1972). It may be relevant that the prevalence of the haplotype HL-A1,8 among Australian Caucasians is high $(9 \%)$ compared with the prevalence of this haplotype among Indians $(0.9 \%)$ and Chinese $(0.06 \%)$ (Ting, 1972). Thus genetic differences expressed through histocompatibility antigens could be a factor accounting for differences in racial prevalence of disease in general, and for the autoimmune type of active chronic hepatitis in particular.

Future studies of relevance would be firstly, the serological analyses of chronic liver disease in Asians residing in Australia and of Australians residing in Asia, provided the numbers were sufficient; and secondly, the analysis of histocompatibility antigens in Asians with chronic liver disease. 
We thank Dr. I. D. Gust of Fairfield Hospital, Melbourne, for performing the tests for HBAg, Dr. G. Kalayasiri for processing specimens of blood, and Miss Julie Robson for skilled technical help. S. W. and I. R. M. were in receipt of a grant from the National Health and Medical Research Council of Australia, and H. K. C. and R. M. were in receipt of a grant from the Indian Council of Medical Research.

\section{References}

Bagshawe, A. F., Parker, A. M., and Jindani, A. (1971). British Medical Fournal, 1,88

Bearn, A. G., Kunkel, H. G., and Slater, R. J. (1956). American fournal of Medicine, 21, 3.

Bhathal, P. S., et al. (1973). Medical fournal of Australia. In press.

Bianchi, P., et al. (1972). Gastroenterology, 63, 482.

Cooksley, W. G. E., et al. (1972). Australian and New Zealand fournal of Medicine, 2, 261.

Doniach, D. (1972). British Medical Bulletin, 28, 145.

Fung, W. P., Tan, K. K., and Tye, C. Y. (1972). Singapore Medical Fournal, 13, 216 .

Gust, I. D., and Kaldor, J. (1971). Pathology, 3, 151.

Harders, H. von, and Dölle, W. (1963). Gastroenterologia (Basel), 100, 220 Hilberg, R. W., Mulhern, L. M., Kenny, J. J., and Luparello, F. J. (1971) Annals of Internal Medicine, 74, 937.
Irvine, W. J., McFadzean, A. J. S., Todd, D., Tso, S. C., and Yeung, R. T. T. (1969). Clinical and Experimental Immunology, 4, 375.

Joske, R. A and Laurence, B. H. (1970). Gastroenterology, 59, 546.

Krook, H. (1961). Acta Medica Scandinavica, 169, 713.

Lee, A. (1973). Australian and New Zealand fournal of Medicine, 3, 268.

Mackay, I. R. (1972) Canadian Medical Association fournal, 106, 519.

Mackay, I. R., and Morris, P. J. (1972). Lancet, 2, 793.

Mackay, I. R., Weiden, S., and Hasker, J. (1965). Annals of the New York Academy of Sciences, 124, 767.

Maclachlan, M. J., Rodman, G. P., Cooper, W. M., and Fennell, R. H. (1965). Annals of Internal Medicine, 62, 425.

Mathews, J. D., and Mackay, I. R. (1970). British Medical fournal, 1, 259

Mistilis, S. P., Skyring, A. P., and Blackburn, C. R. B. (1968). Australasian Annals of Medicine, 17, 214.

Popper, H., Paronetto, F., and Schaffner, F. (1965). Annals of the New York Academy of Sciences, 124, 781 .

Read, A. E., Sherlock, S., and Harrison, C. V. (1963). Gut, 4, 378.

Reynolds, T. B., Edmondson, H. A., Peters, R. L., and Redeker, A. (1964). Annals of Internal Medicine, 61, 650.

Ting, A. (1972). In $A$ Genetic and Anthropological Study, Ph.D. Thesis, University of Melbourne.

Vischer, T. L. (1971). Progress in Allergy, 15, 268.

Weiden, S. (1953). Medical fournal of Australia, 1, 364

Weiden, S. (1953). Medical fournal of Australia, 1, 364. Fournal, and Fudenberg,

Whittingham, S. (1972). In Research in Immunochemistry and Immunobiology, ed. J. B. G. Kwapinski, vol. 1, p. 121. Baltimore, University Park Press.

Whittingham, S., and Mackay, I. R. (1969). Medical fournal of Australia, 1,1200 .

Whittingham, S., Mackay, I. R., and Kiss, Z. S. (1970). Gut, 11, 811

\title{
Changes in Skeletal Mineral in Patients on Prolonged Maintenance Dialysis
}

\author{
P. J. ATKINSON, \\ D. A. HANCOCK, \\ V. N. ACHARYA, \\ F. M. PARSONS, \\ E. A. PROCTOR, \\ G. W. REED
}

abnormal vitamin D metabolism (Genuth et al., 1969), and increased parathyroid activity commonly leads to excessive bone resorption (Kleeman et al., 1970). Thus, both osteomalacic and fibrocystic bone changes are found. Such disturbed calcium

\section{Summary}

The measurement of bone loss in patients undergoing maintenance dialysis over a period of two and a half years is reported. The tendency to lose bone is a likely event in renal failure, but depends more on the individual patient than on the type of dialysis used, provided that steps are taken to prevent avoidable calcium loss during dialysis. Vitamin $D$ therapy was an important factor in preventing bone loss in some cases. The tendency to lose bone more readily when both kidneys were absent may have reflected a deficiency of 1-25 dihydrocholecalciferol. On the other hand, bone loss was also observed in transplanted patients. The need to measure bone loss at regular intervals once renal failure has been diagnosed is stressed.

\section{Introduction}

Calcium metabolism is always disturbed in chronic renal failure. Absorption of dietary calcium is reduced as a result of

\section{University of Leeds, Leeds 1}

P. J. ATKINSON, M.R.C.S., PH.D., Senior Lecturer in Oral Biology D. A. HANCOCK, M.SC., Research Assistant in Medical Physics

G. W. REED, M.SC., Senior Lecturer in Medical Physics

\section{General Infirmary, Leeds 1}

F. M. PARSONS, M.D., F.R.C.P., Consultant in Clinical Renal Physiology E. A. PROCTOR, M.B., B.S., Registrar, Renal Research Unit (Now at Royal Devon and Exeter Hospital, Exeter)

V. N. ACHARYA, M.D., Nuffield Foundation Travelling Fellowship in Medicine, Renal Research Unit (Now at Department of Medicine, Seth G.S. Medical College, Bombay 12) metabolism almost invariably leads to an increased rate of bone resorption which is often associated with the deposition of calcium salts in soft tissues. The difficulty of assessing metabolic balance studies under these circumstances is formidable, but a better understanding about the state of the bone mineral in chronic renal failure can be achieved by measuring the loss of bone.

A previous paper reported a scanning technique which uses the $60 \mathrm{keV}$ emission from the isotope ${ }^{241} \mathrm{Am}$ to measure the bone mineral in the femoral shaft of patients on maintenance dialysis (Atkinson et al., 1970). Measurements made at monthly intervals over 40 weeks showed that 13 patients had a tendency to lose bone mineral. The present paper reports changes in the bone mineral in 15 patients during a much longer period (two and a half years) which includes the time covered by the initial report.

\section{Method}

Measurements of bone mineral have been made on a control group of subjects and on 15 patients receiving maintenance dialysis for chronic renal failure. At the beginning of this study six patients were being treated by peritoneal dialysis and seven by haemodialysis. This therapy was maintained during the first 40 weeks (table I). After two and a half years two remained on peritoneal dialysis; six, together with two new patients, were on haemodialysis; and two had received transplants (three had discontinued bone measurements). Only in the two transplanted patients was there any significant renal excretion; of the dialysed 